\title{
Problem Pemberian Amnesti oleh Presiden Dalam Perspektif Kepentingan Negara
}

\author{
Rizky Malinto Ramadani*, Indra Perwira, Bilal Dewansyah \\ Program Magister Ilmu Hukum Universitas Padjadjaran \\ Jl. Banda No.42, Bandung-Jawa Barat \\ *Correspondence email: rizkymalintor04@gmail.com, Perwira78@gmail.com, b.dewansyah@unpad.ac.id
}

\begin{abstract}
Abstrak. Pasal 14 Ayat (2) UUD 1945 menentukan Presiden Memberi Amnesti dan Abolisi dengan memperhatikan pertimbangan Dewan Perwakilan Rakyat. dalam ketentuan Pasal (1) Undang - Undang Darurat No. 11 tahun 1954 tentang Amnesti dan Abolisi menyebutkan bahwa "Presiden atas kepentingan negara, dapat memberi Amnesti dan Abolisi kepada orang - orang yang telah melakukan sesuatu tindakan pidana. Presiden memberi Amnesti dan Abolisi ini setelah mendapatkan nasihat tertulis dari Mahkamah Agung yang menyampaikan nasihat itu atas permintaan Menteri Kehakiman”. Persoalan terkait amnesti tidak ada kejelasan lebih rinci mengenai kriteria pemberian amnesti untuk kepentingan negara ini apakah pemberian amnesti ini hanya ditujukan untuk kasus yang bermuatan politik saja atau bisa diberikan juga untuk tindak pidana umum, apalagi dalam sejarahnya amnesti diberikan hanya untuk kejahatan politik semata. Adapun identifikasi Masalah dalam penelitian ini yaitu Pertama sejauh mana pemberian amnesti di Indonesia sesuai dengan kriteria kepentingan negara. Metode yang digunakan peneliti dalam penelitian ini adalah yuridis normatif. Hasil dari penelitian ini menunjukkan bahwa Kriteria paling penting dari adanya kepentingan negara adalah stabilitas sistem ketatanegaraan serta jaminan hak-hak bagi warga negara. Adapun syarat ideal yang perlu diatur dalam amnesti yaitu: Pembatasan Amnesti tidak diberikan untuk extraordinary crime; tidak boleh untuk impeachment Presiden. Sedangkan untuk prosedur yang ideal selain tetap mengacu pada UUD 1945 dan Peraturan Menteri Sekretaris Negara, pemberian amnesti juga harus juga meminta pertimbangan Mahkamah Agung, agar pemberian amnesti ini tidak hanya dilihat untuk kepentingan politik saja, namun juga dilihat dari kepentingan negara.
\end{abstract}

Kata Kunci: Amnesti; Presiden; Kepentingan Negara

Abstract. Article 14 Paragraph (2) of the 1945 Constitution determines that the President grants amnesty and abolition by taking into account the considerations of the House of Representatives. in the provisions of Article (1) of the Emergency Law no. 11 of 1954 concerning Amnesty and Abolition states that "The President, in the interest of the state, can grant amnesty and abolition to people who have committed a criminal act. The President granted this amnesty and abolition after obtaining written advice from the Supreme Court which conveyed the advice at the request of the Minister of Justice." The issue related to amnesty is that there is no more detailed clarity regarding the criteria for granting amnesty for the benefit of this country, whether the granting of amnesty is only intended for politically charged cases or can also be given for general criminal acts, especially in history, amnesties have been granted only for political crimes. The identification of the problems in this study are: First, the extent to which the granting of amnesty in Indonesia is in accordance with the criteria of the state's interest. The method used by researchers in this study is normative juridical. The results of this study indicate that the most important criterion of the existence of the state's interest is the stability of the state administration system and the guarantee of rights for citizens. The ideal conditions that need to be regulated in amnesty are: Amnesty restrictions are not granted for extraordinary crimes; not allowed to impeach the President. As for the ideal procedure, apart from referring to the 1945 Constitution and the Regulation of the Minister of State Secretary, the granting of amnesty must also ask for consideration from the Supreme Court, so that the granting of amnesty is not only seen for political interests, but also for the interests of the state.

Keywords: Amnesty; President; State Interest

\section{PENDAHULUAN}

Amnesti termasuk dalam salah satu kewenangan presiden untuk mengampuni narapidana baik sebelum ataupun sesudah diputuskan oleh pengadilan. Ketentuan mengenai amnesti diatur dalam ketentuan pasal 14 UUD 1945 sebelum amandemen bahwa "Presiden Memberi Grasi, Amnesti, Abolisi dan Rehabilitasi" dan diperbaharui dengan ketentuan pasal 14 Ayat (2) UUD 1945 sesudah amandemen "Presiden Memberi Amnesti dan Abolisi dengan memperhatikan pertimbangan Dewan Perwakilan Rakyat". Dengan demikian setelah perubahan, Amnesti bukan merupakan Hak mutlak Presiden melainkan harus dengan pertimbangan Dewan
Perwakilan Rakyat. Akan tetapi dalam ketentuan Pasal (1) Undang - Undang Darurat No. 11 tahun 1954 tentang Amnesti dan Abolisi menyebutkan bahwa

"Presiden atas kepentingan negara, dapat memberi Amnesti dan Abolisi kepada orang - orang yang telah melakukan sesuatu tindakan pidana. Presiden memberi Amnesti dan Abolisi ini setelah mendapatkan nasihat tertulis dari Mahkamah Agung yang menyampaikan nasihat itu atas permintaan Menteri Kehakiman”. 
Pada awal kemerdekaan sampai awal reformasi pemberian amnesti lebih sering diberikan kepada narapidana yang menjadi tahanan politik pemerintah yang berkuasa, bukan diberikan kepada narapidana kasus kejahatan umum. Contohnya pengampunan pada pimpinan dan anggota dari pemberontak Gerakan Aceh Merdeka (GAM) oleh mantan Presiden Susilo Bambang Yudhoyono pada 2005 dengan tujuan terjadi rekonsiliasi antara kedua pihak yang berujung dengan kesepakatan damai dan kesediaan kembali menjadi bagian dari NKRI. Namun dalam perkembangannya pemberian amnesti untuk narapidana kasus tindak pidana umum juga diberikan presiden pada kasus Baiq Nuril tahun 2018. ${ }^{1}$

Praktik pemberian Amnesti terakhir dilakukan oleh Presiden Joko Widodo memberikan amnesti kepada Baiq Nuril karena banyaknya aspirasi dan desakan kuat dari berbagai elemen masyarakat yang beranggapan putusan Mahkamah Agung yang menghukum Baiq Nuril atas pelanggaran UU Nomor 11 Tahun 2008 tentang Undang-undang Informasi dan Transaksi Elektronik (ITE).

Alasan pemberian Amnesti yang dilakukan oleh Presiden Joko Widodo dalam hal ini tidak terdapat kejelasan lebih rinci mengenai kriteria pemberian amnesti untuk kepentingan negara. Dalam hal ini, problem pemberian amnesti ini hanya ditujukan untuk kasus yang bermuatan politik saja atau bisa diberikan juga untuk tindak pidana umum.

Mengacu pada kasus Baiq Nuril bahwa banyak narapidana yang seharusnya tidak layak untuk dipidana, mengajukan permohonan amnesti ditolak oleh Presiden, sebab tidak memenuhi unsur kepentingan negara. Contohnya pada tahun 2010 Aktivis agraria Eva Susanti Bande ditangkap dengan tuduhan penghasutan kepada warga petani yang merasa lahan mereka diambil paksa oleh perusahaan. Namun kasus ini tidak banyak diperhatikan oleh publik meskipun banyak aktivis dan Elemen masyarakat yang mendesak presiden untuk memberikan amnesti pada Eva Susanti, namun permohonan itu ditolak. Berdasarkan alasan kepentingan negara maka seharusnya presiden bisa saja memberikan amnesti kepada Eva Susanti Bande secepat proses pemberian amnesti kepada Baiq Nuril akan tetapi hal itu tidak dilakukan sampai ditahun 2014 Presiden memberikan Grasi. ${ }^{2}$

${ }^{1}$ Lihat BBC News, Kasus Baiq Nuril: Perempuan yang dipidanakan karena merekam percakapan mesum akan 'tagih amnesti' ke Jokowi, artikel, dimuat dalam

https://www.bbc.com/indonesia/indonesia-48878086 diakses pada 4 November 2020.

2 Siti Rakhma Mary Herwati,Pemberian Amnesti, Abolisi, dan Rehabilitasi untuk Para Pejuang Agraria Demi Keadilan, Bogor: Policy Paper Sajogyo Institute No. 1,2015, Tanpa halaman.
Adanya disparitas pemberian amnesti tersebut menunjukkan bahwa saat ini amnesti untuk kepentingan negara justru diberikan hanya pada kasus-kasus yang viral dan menarik perhatian masyarakat yang luas, sehingga desakan masyarakat ini yang menekan Presiden untuk memberikan amnesti. Menjadi pertanyaan apakah amnesti terhadap narapidana pidana umum ini benarbenar bertujuan untuk kepentingan negara ataukah bergeser untuk kepentingan politik tertentu. Keputusan Presiden dalam memberikan amnesti menimbulkan asumsi bahwa amnesti nantinya dijadikan sarana untuk momentum tertentu, karena tidak adanya peraturan yang secara eksplisit mengenai syarat untuk mendapatkan Amnesti untuk kepentingan negara ini.

Perkembangan pemberian amnesti yang dilakukan oleh Presiden menjadi menarik untuk dianalisis lebih mendalam selain tentang ketentuan kriteria yang seharusnya ditetapkan dalam pemberian Amnesti. Dalam hal ini, penting untuk dilihat apakah pemberian amnesti kedepannya harus disesuaikan dengan kriteria yang telah ditetapkan. Oleh sebab itu penting untuk diuraikan pemberian amnesti dan kriteria pemberian amnesti di Indonesia.

\section{Perumusan Masalah}

Permasalahan yang diajukan dalam penelitian ini adalah sejauh mana pemberian amnesti di Indonesia sesuai dengan kriteria kepentingan negara. ?

\section{METODE}

Penelitian ini merupakan penelitian yuridisnormatif dengan menggunakan pendekatan perundangundangan, pendekatan kasus serta pendekatan konsep Melalui tiga pendekatan tersebut dapat terlihat maksud adanya pemberian amnesti yang ideal, dimana akan sesuai dengan ketentuan sekaligus tidak berdasarkan prinsip kepentingan dari Presiden yang notabennya merupakan jabatan yang tidak terlepas dari kepentingan politik.

\section{HASIL DAN PEMBAHASAN \\ Pengaturan Pemberian Amnesti di Indonesia}

Presiden merupakan pemegang kekuasaan pemerintahan negara sebagai kepala negara sekaligus kepala pemerintahan. Jimly Asshidiqie mengatakan kedua jabatan baik kepala negara dan kepala pemerintahan pada hakikatnya termasuk dalam cabang kekuasaan eksekutif. ${ }^{3}$ Oleh karena itu kedudukan presiden sangat kuat, sehingga harus ada kedudukan Presiden harus dibatasi oleh konstitusi dalam sistem republik yang demokratis. ${ }^{4}$

3 Jimly Asshidiqie. Pokok-Pokok Hukum Tata Negara Indonesia. Pasca Reformasi, (Jakarta: PT Bhuana Ilmu Populer.2007.Hlm 311.

${ }^{4}$ Ibid., Hlm 314 
Ismail Suny menyatakan bahwa kekuasaan yang dimiliki oleh Presiden secara umum yang diatur dalam UUD yaitu: ${ }^{5}$

1. Kekuasaan administratif yaitu pelaksanaan UU dan politik administrasi;

2. Kekuasaan legislatif yaitu mengusulkan rancangan undang-undang dan mengesahkan undang-undang;

3. Kekuasaan yudikatif terkait kekuasaan presiden memberikan grasi, rehabilitasi, amnesti, abolisi;

4. Kekuasaan militer yaitu kekuasaan mengenai angkatan perang dan pemerintahan;

5. Kekuasaan diplomatik yaitu kekuasaan hubungan luar negeri

Dalam kedudukan selaku Kepala Negara republik Indonesia, Presiden Indonesia mempunyai kekuasaankekuasaan yang ditetapkan dalam UUD 1945 pasal 10, 11, 12, 13, 14, dan 15. Jadi kekuasaan seorang Presiden sudah sah dan terjamin menurut aturan hukum yang berlaku dan sudah diatur dalam Undang-Undang dasar. Penjelasan UUD 1945 menegaskan, bahwa meskipun Kepala Negara Indonesia tidak bertanggung jawab kepada DPR, ia bukanlah "diktator" kekuasaan tidak terbatas, oleh karena dalam melaksanakan tugas eksekutif Presiden tak luput dari pengamatan MPR, suatu lembaga Negara Tertinggi yang berwenang memberhentikan Presiden walaupun belum habis masa jabatannya. ${ }^{6}$

Secara khusus, kewenangan presiden di bidang yudisial secara normatif telah diatur dalam pasal 14 ayat (1) dan ayat (2) UUD 1945. Pasal 14 ayat (1) menyatakan bahwa: "Presiden memberi grasi dan rehabilitasi dengan memperhatikan pertimbangan Mahkamah Agung". Sedangkan pasal 14 ayat (2) UUD 1945 menyatakan "Presiden memberi amnesti dan abolisi dengan memperhatikan pertimbangan DPR". Pertimbangan dari Mahkamah Agung dan DPR kepada Presiden sangat penting untuk mewujudkan mekanisme check and balances antara Presiden dengan DPR.

Perihal pengaturan hukum amnesti dan abolisi mulai diatur pertama kali pada undang - undang darurat Nomor 11 tahun 1954 sebagai pertimbangan untuk melaksanakan ketentuan dalam pasal 107 Undangundang Dasar Sementara Republik Indonesia dan untuk menyesuaikan penetapan Presiden Republik Indonesia No. 14 tahun 1949 tentang pemberian amnesti. Terkait dengan pemberian amnesti kepada semua orang yang sebelum tanggal 27 Desember 1949 telah melakukan sesuatu tindak pidana yang nyata akibat dari persengketaan politik antara Republik Indonesia (Yogyakarta) dan Kerajaan Belanda. ${ }^{7}$ Dalam UU Darurat

${ }^{5}$ Ismail Suny, Pembagian Kekuasaan Negara, Jakarta: Aksara Baru, 1978. Hlm. 328

${ }^{6}$ C.S.T Cansil, Sistem Pemerintahan Indonesia, Aksara Baru, Jakarta, 1985, hlm. 106.

${ }^{7}$ Pasal 2 UU darurat No. 11 tahun 1954. itu tidak mengatur lebih rinci defenisi mengenai amnesti dan abolisi, hanya dalam pasal 1 UUDS 1950 pemberian pengampunan ini diatur oleh presiden atas kepentingan negara. Ketentuan amnesti dapat berikan berdasarkan kepentingan negara kepada orang - orang yang melakukan tindak pidana dengan mendapat pertimbangan tertulis oleh mahkamah agung berdasarkan permintaan menteri kehakiman. ${ }^{8}$ Presiden memberikan amnesti berdasarkan kepentingan negara, karena hal tersebut belum diatur secara rinci dalam undang undang darurat tahun 1954 sehingga memungkinkan terjadi berbagai macam tafsir serta penyalahgunaan kekuasaan.

Pengaturan mengenai amnesti berkembang dengan berlakunya undang - undang dasar 1945 yang mengatur mengenai amnesti. Ketentuan mengenai amnesti pada undang - undang dasar 1945 terdapat perbedaan dengan UU Darurat tahun 1954 pada pasal 14 ayat (2) UUD 1945 sesudah amandemen 'Presiden memberi amnesti dan abolisi dengan memperhatikan pertimbangan Dewan Perwakilan Rakyat'. Penjelasan pasal ini memberikan penafsiran bahwa amnesti merupakan hak berdasarkan konstitusi. Pemberian amnesti membutuhkan pertimbangan hukum bukan pertimbangan politik. Pasal 96 dan 107 UUD Sementara yang sekarang telah digantikan dengan Pasal 14 ayat (2) UUD 1945.

UU Darurat Nomor 11 Tahun 1954 tentang Pemberian Amnesti dan Abolisi dilahirkan karena saat itu ada kondisi yang mendesak guna kepentingan negara untuk seseorang atau sekelompok orang yang telah melakukan suatu tindakan pidana sehingga dibutuhkan peraturan yang memberi legalitas atas amnesti dan abolisi.

Berdasarkan penyesuaian yang dijelaskan dalam pasal 2 dan 3 UU Darurat ini. Selain menambahkan frasa abolisi diantara amnesti dan diberikan penyesuaian sehingga instansi yang disebut dalam penetapan presiden itu tidak berlaku lagi, sehingga penyelenggaraan amnesti dan abolisi harus dilakukan menurut UU Darurat selama belum ada peraturan baru yang menggantikan aturan ini.

Berdasarkan pasal 3 UU Darurat No. 11 Tahun 1954, tahapan dalam memberikan amnesti hanya dapat diberikan dengan undang-undang ataupun atas kuasa undang-undang oleh Presiden sesudah meminta nasehat dari Mahkamah Agung, dan penyelenggaraan amnesti dan abolisi harus dilakukan menurut peraturan UU darurat ini seluruh peraturan terdahulu tentang amnesti dan abolisi tidak berlaku lagi. ${ }^{9}$

Dalam hal yang demikian, UU Nomor 11 Tahun 1954 tentang Amnesti dan Abolisi mengatakan presiden dapat memberikan amnesti setelah mendapat nasihat tertulis dan Mahkamah Agung yang diminta terlebih

\footnotetext{
${ }^{8}$ Pasal 1 UU darurat No. 11 TAHUN 1954.

${ }^{9}$ Penjelasan Undang-Undang Darurat Nomor 11 tahun 1954 Tentang Amnesti dan Abolisi.
} 
dulu oleh kementerian terkait (dalam hal ini Kementerian Hukum dan Hak Asasi Manusia). Sedangkan menurut UUD 1945 pasal 14 ayat (2), pemberian amnesti presiden harus dengan pertimbangan Dewan Perwakilan Rakyat (DPR). Persoalan yang timbul adalah kedua aturan yang ada terkait pemberian amnesti dari presiden, memberikan petunjuk yang berbeda terkait mekanisme amensti yang harus dijalani.

Merujuk pada UU Darurat No.11 Tahun 1954 bersifat sekali selesai dan hanya diperuntukkan pada saat itu saja, sebab UU darurat ini diperuntukkan kepada semua orang yang sebelum tanggal 27 Desember 1949 telah melakukan suatu tindak pidana yang nyata akibat dari persengketaan politik antara Republik Indonesia dan Kerajaan Belanda (Pasal 2 UU Darurat No.11 tahun 1954). Namun anehnya sampai sekarang UU darurat ini masih berlaku belum dicabut, bahkan pemberian amnesti yang telah diberikan kepada individu ataupun kelompok ini masih berdasarkan kepada UU Darurat ini. Merujuk pada konsideran menimbang UU darurat 11 Tahun 1954, UU ini masih mengacu pada UUDS 1950. Padahal UUDS 1950 bukan lagi menjadi konstitusi yang dipakai saat ini. Menjadi persoalan ketika UU darurat yang mengacu pada konstitusi yang tidak lagi berlaku masih digunakan padahal mekanisme amnesti UU Darurat berbeda dengan UUD 1945 hasil amandemen. Hal inilah yang kemudian ,elhairkan berbagai persepsi bahwa amnesti itu hanya bisa diberikan untuk kejahatan politik karena UU No. 11 Tahun 1954 konteksnya lebih ditujukan pada narapidana politik.

Sejetinya, ketentuan dalam UU Darurat No. 11 Tahun 1954 Amenesti dan Abolisi sudah tidak lagi relevan sebab norma konstitusi yang menjadi rujukannya sudah gugur dengan Pasal 14 UUD 1945 setelah amandemen. Dilihat dari sejarahnya UU Darurat ini adalah pelaksana dari Pasal 107 UUDS 1950 yang mana konstitusi tersebut sudah tidak berlaku lagi sejak Dekrit Presiden 5 Juli 1959. Dalam Pasal 107 konstitusi sementara tersebut disebutkan bahwa pemberian amnesti, abolisi dan grasi harus dengan kuasa UU dan meminta pendapat Mahkamah Agung.

Pengaturan amnesti dan abolisi lebih sumir lagi jika mengacu pada UU No. 22 Tahun 2002 jo UU No. 5 Tahun 2010 yang masih tidak menjelaskan amnesti dan abolisi secara jelas. Hal ini menjadi bukti bahwa UU Darurat No.11 Tahun 1954 memang konteksnya diberikan untuk keadaan darurat negara saat itu karena adanya gejolak politik yang kuat saat itu. Jadi kepentingan negara saat itu lebih mengarah karena keadaan politik yang bergejolak saat itu. Apalagi UU Darurat ini sebenarnya didasarkan kepada UUDS 1950. UU No. 11 Drt Tahun 1954 perlu segera diganti karena muatan materi sebagaimana diatur Pasal 2 dan Pasal 3 sudah tidak sesuai dengan praktik ketatanegaraan, dinamika kehidupan berbangsa dan bernegara, serta kebutuhan hukum masyarakat. UU No. 11 Tahun 1954 bisa dikatakan bertentangan dengan UUD Tahun 1945.

\section{Kriteri Kepentingan Negara Dalam Pemberian Amnesti.}

Menurut Norman J. Padelford, kepentingan nasional adalah National interest of a country is what a governmental leaders and in large degree also what its people consider at any time to be vital to their national independence, way of life, territorial security and economic welfare. ${ }^{10}$ Sementara itu, Thomas W. Robinson dengan mengutip Hans Morgenthau secara umum mendefinisikan kepentingan nasional kedalam 6 tipe, yaitu: ${ }^{11}$

(a) Primary interest, yang berarti bahwa kepentingan nasional bertujuan untuk melindungi pertahanan keamanan negara, sistem politik dan identitas nasional;

(b) Secondary interest, yaitu kepentingan nasional untuk melindungi warga negaranya di luar negeri;

(c) Permanent interest, diartikan sebagai kepentingan nasional yang bertujuan untuk mencapai kepentingan-kepentingan negara dalam periode masa tertentu;

(d) Variable interest, yaitu kepentingan nasional dapat berdasarkan pada opini publik dan situasi politik dalam negeri;

(e) General interest, adalah kepentingan nasional juga berkaitan dengan perilaku positif berdasarkan luas dan letak geografis, jumlah populasi, serta beberapa aspek seperti ekonomi, perdagangan, diplomasi dan hukum internasional;

(f) Specific interest, berarti bahwa kepentingan nasional berkaitan pada waktu dan isu tertentu.

Sementara itu, menurut Rochester, terdapat dua asumsi yang berkaitan dengan konsep kepentingan negara yaitu: "there exist and objectively determinable collective interest which all individual members within a given national society share equality, and this collective transcends any interest that a particular subset of those individuals may share with individuals in other national societies". ${ }^{12}$ secara umum kepentingan negara bisa dimaknai sebagai sesuatu yang melekat pada negara yang dipengaruhi oleh kepentingan kolektif dari masyarakat negara itu sendiri, sehingga kepentingan kolektif ini bisa dibagi kepada negara lain. ${ }^{13}$

Konsep national interest lebih merupakan metafora yang membangun kesadaran suatu bangsa

10 Norman J. Padelford and George A. Lincoln, International Politics, The Macmillan Company, New York, 1960, hal. 309

11 Robinson Thomas W. 1969. "National Interest". dalam James N. Rosenau (ed.). International Politics and Foreign Policy.London: the Free Press. 183

12 J. Martin Rochester. The national interest and contemporary world politics. The review of politics Vol. 40 No. 1. 1978. Hlm 79.

13 Ibid., 
untuk membentuk pertahanan diri, bagaimanapun kepentingan nasional merupakan nilai-nilai abadi yang kebal terhadap tren atau tujuan politik. ${ }^{14}$ untuk menghasilkan sistem kepentingan nasional yang matang membutuhkan konsensus publik tentang ide-ide dasar dalam bernegara. konsep kepentingan nasional tidak dapat dipisahkan dari mekanisme melalui kepentingan kelompok, sosial individu, masyarakat yang dirumuskan dalam suatu kepentingan yang dapat menjadi perhatian negara. ${ }^{15}$

Kepentingan nasional memiliki faktor-faktor yang harus dipertimbangkan yaitu lokasi, peradaban masyarakat (civilization), nature of society (perilaku masyarakat) atau perubahan terkait (economic qualities, share of the world economy, important resources). ${ }^{16}$ I.G Iakovenko mengatakan bagaimanapun kepentingan nasional memiliki dua bentuk yaitu pertama secara objektif (national interests from God's standpoint) dan dari sudut subjektif (hasil intrepretasi masyarakat tentang kepentingan negara ini. kepentingan negara terkadang harus disesuaikan dengan desakan publik. ${ }^{17}$

Merujuk pada pemaknaan terhadap kepentingan negara tersebut, maka sejatinya kepentingan negara haruslah menjadi landasan dan tujuan dalam sebuah pengambilan kebijakan. Termasuk diantaranya pengambilan kebijakan oleh Presiden dalam memberikan keputusan Amnesti kepada seseorang. Maksud dan tujuan tersebut sejatinya harus diatur dan dikonstruksikan secara hukum agar kepentingan tersebut terwujud sesuai dengan apa yang telah ditetapkan sebelumnya. Sejatinya, terdapat dua maksud yang dijaga dalam suatu kepentingan negara, yakni kepentingan secara umum bagi negara itu sendiri, serta kepentingan secara khusus yang berkaitan erat dengan hak asasi warga negara. Dalam hal ini, kriteria kepentingan negara yang dimaksud memang tidak diuraikan secara konkrit dalam peraturan perundang-undangan yang ada di Indonesia.

Adapun maksud dari kepentingan secara umum bagi negara adalah adanya suatu kebijakan hukum yang dimaksudkan untuk menjamin kepentingan negara dengan tetap memperhatikan konsekuensi dari kebijakan tersebut yaitu tidak terganggunya keberlangsungan kehidupan ketatanegaraan. Pilihan terhadap suatu kebijakan hukum sejatinya tidak berakibat pada sistem ketatanegaraan yang ada, namun justru sebaliknya akan memberikan dukungan sepenuhnya pada keberlangsungan ketatanegaraan.

Sementara itu, kepentingan negara yang secara khusus ialah kepentingan dari suatu kebijakan hukum yang dipilih oleh negara dengan menjamin serta

14 S.S Mirotokhin. The Potential of National interest. hlm 11

\footnotetext{
${ }^{15}$ I.G Iakovenko. Dynamic Interest hlm 16

${ }^{16}$ Ibid., hlm 17

${ }^{17}$ Ibid., hlm 20
}

melindungi hak-hak dari warga negara sebagai subjek hukum sekaligus sebagai salah satu unsur paling penting dalam suatu negara. Dengan demikian, lahirnya suatu kebijakan hukum dengan disertai terwujudnya kepentingan dari negara tidak hanya memperhatikan sistem ketataneagraan semata, namun juga secara nyata dapat dirasakan oleh warga negara.

Adanya kejelasan kepentingan negara dalam pemberian suatu amnesti akan sejalan dengan hal-hal administratif lainnya, seperti kriteria, persyaratan, jangka waktu pengajuan, dan proses pengajuan. Hal ini penting untuk diatur agar tidak menimbulkan multiinterpretasi dan multitafsir dalam praktek pelaksanaan pemberian amnesti. Sehingga hak preogratif Presiden yang terdapat dalam Pasal 14 UUD 1945 tersebut dapat diatur dengan baik dan tidak menimbulkan perdebatan hukum dalam penerapannya.

Merujuk pada perdebatan perumus Pasal 14 ayat 2 UUD 1945 amendemen. Dalam pembahasan itu, para perumus tidak terlalu memperdebatkan hak presiden memberikan amnesti dipakai untuk kasus apa saja. Syarat pemberian amnesti jika merujuk kepada aturan universal antara lain: ${ }^{18}$

1. telah menyatakan makar terhadap negara

2. memiliki organisasi kemiliteran

3. memiliki struktur militer

4. menguasai teritorial atau kewilayahan

5. diakui keberadaannya oleh negara sendiri serta dunia internasional

Perihal pemberian Amnesti, terdapat beberapa hal penting yang berkaitan dengan instrumen internasional. Hal tersebut adalah sebagai berikut: ${ }^{19}$ Pertama, "Prisoners of conscience" bagi mereka yang telah mencapai kata damai melalui advokasi politik harus dilepas tanpa syarat. Tipe ini berbeda dengan status tahanan politik dimana orang tersebut dijerat karena melakukan perbuatan yang bermotif politik. Hal ini diperkuat oleh Resolusi Dewan HAM 9 Juni 2011. Tafsir otoritatif Komite HAM menjelaskan bahwa "setiap orang bebas meyakini opini tentang pandangan politik, moral, nilai religus tidak dapat dibatasi oleh aturan hukum apapun. Pembatasan hak beropini ini baik dalam bentuk pelecehan, intimidasi, atau stigmatisasi seseorang termasuk penangkapan, penahanan, atau pemenjaraan melanggar Kovenan Hak-Hak Sipil dan Politik. ${ }^{20}$ Pembatasan terhadap hak berpendapat hanya bisa dibatas jika mengandung unsur kebencian

18 Telaah kasus Din Minimi Dalam Sudut Pandang Hukum, Politik dan Korban http://www.jsithopi.org/2016/02/telaah-kasus-din-minimidalam-sudut-pandang-hukum-politik-dan-korban

19 Lihat Kontras. Mempertimbangkan Amnesti Bagi Tahanan Politik Papua. Hal 3-5.

${ }^{20}$ Human Rights Committee General Comment No. 34, UN Doc. CCPR/C/GC/34, September 2011, Hal 5 dan 9 
berdasarkan agama, ras, etnis, atau kebangsaan (sekarang dikenal dengan istilah hate speech). Kedua, amnesti dapat diberikan bagi narapidana yang melakukan tindak pidana ringan yang memiliki muatan politik. Pemerintah yang paling berwenang apakah amnesti diberikan atau tidak. Amnesti perlu dipertimbangkan terutama bagi tahanan politik yang dihukum karena putusan pengadilan yang tidak adil, bahkan rekayasa politik. Pemberian amnesti untuk tahan politik ini lebih bersifat pragmatis, agar tahanan ini bisa dibebaskan baik secara damai, rekonsiliasi ataupun dialog.

Ketiga, hukum internasional tentang HAM dan humaniter melarang pemberian amnesti terutama bagi kejahatan genosida, kejahatan kemanusiaan, dan kejahatan perang. Selain itu pelaku (extra-judicial execution) seperti penyiksaan, perkosaan tidak layak mendapatkan amnesti. Bagi tahanan politik yang dianggap sebagai pelaku kejahatan serius ini namun tidak mendapat proses peradilan yang adil, harus diadili ulang.

Pemberian pengampunan (pardoning power) dibatasi oleh bidang kekuasaan kehakiman (office of the united states pardon attorney of the department of justice) yang bertugas memberikan Rekomendasi kepada Presiden mengenai pengampunan yang layak diberikan. Demikian pula di Inggris yang dipimpin seorang raja/ratu tetap pemberian "Royal Pardon" dibatasi oleh "the Secretary of State for Home Affairs" yang berwenang memberikan nasihat mengikat untuk memberikan hak prerogatif kerajaan "Royal Prerogative of Mercy" layak diberikan atau tidak.

Partisipasi dan transparansi ini yang mutlak diperbaiki. Pemerintah bersama DPR harus memetakan regulasi yang berkaitan secara rinci karena pengaturan yang tidak lengkap, terutama mengenai amnesti dan abolisi, bahkan konteks (historis) menuntut untuk dilakukan pembaharuan hukum karena baik alasan filosofis (alasan ideal, seperti perlu tidaknya pembatasan kekuasaan Presiden dalam hal itu atau mutlak), maupun alasan sosiologis (seperti melepaskan amnesti dan abolisi dari semata-mata berhubungan dengan kasus politik sebagai tergambar dalam sejarahnya di Indonesia).

Dalam hal yang demikian, pemberian amnesti di Indonesia seharunsya dilakukan atas berbegai pertimbangan sebagai berikut:

- Tidak boleh untuk impeachment; Hak hak yang dapat dipertanggung jawabkan seperti seorang presiden tidak dapat menggunakan amnesti apabila terjadi pemakzulan (Impeachment) atau disebut dengan self amnesti di Amerika Serikat yang dilakukan DPR.

- Perlu diatur tentang apakah orang yang telah mendapatkan amnesti masih perlu mendapatkan berhak mendapatkan rehabilitasi. Perlu diatur juga agar ketika seseorang di beri amnesti tidak dapat digugat melalui jalur perdata terkait perbuatannya sebelum diamnesti.

Penggunaan hak prerogatif dalam pemberian amnesti sudah seharusnya tidak digunakan oleh Presiden sekehendaknya. Presiden perlu mempertimbangkan kriteria filosofis berdasarkan asas-asas tidak mengandung cacat karena didasarkan pada iktikad baik (dwaling), tidak mengandung unsur penipuan (bedrog), dan tidak mengandung paksaan (dwang) yang menyebabkan akibat-akibat hukum yang tidak sah. Pemberian amnesti juga seringkali disebut sebagai wewenang yudikatif presiden. Wewenang ini harus dimaknai sebagai upaya menyelamatkan kepentingan negara terhadap kekacauan sistem hukum dan/atau kekhilafan dalam proses hukum. ${ }^{21}$

- Orang yang telah mendapatkan Amnesti tidak dapat lagi dituntut secara perdata maupun pidana (oleh sanak-keluarga korban, misalnya), karena tanggung jawab itu sudah diambil alih oleh negara. Negaralah yang harus membayar kompensasi atau restitusinya. Pelaksanaan Amnesti diberikan ketika hukum sudah diputuskan. Misalnya seseorang diputuskan bersalah dan mendapat hukuman 20 tahun penjara atau terpidana seumur hidup. Maka, ketika sudah berjalan penjara 2 tahun mendapatkan Amnesti, hukuman dihapuskan. Dia tidak lagi menjalani hukuman selanjutnya.

Sementara itu, prosedur dalam pemberian amnesti harus dilakukan dalam beberapa langkah berikut:

1. Penetapan terhadap lembaga khusus yang akan mengintrodusir adanya permohonan dari narapidana untuk mendapatkan Amnesti. perlu diatur dengan tegas tentang lembaga dan/atau kementerian mana yang mengajukan amnesti kepada presiden agar jelas dan tidak tumpang-tindih. Dalam hal ini, penulis menetapkan kementerian Sekretariat Negara sebagai lembaga khusus yang akan melakukan tugas tersebut. pada tahap ini dilakukan verifikasi terhadap setiap permohonan yang diajukan.

2. Permohonan amnesti dilakukan harus dengan tas pertimbangan hukum dan politik. Setelah Kementerian Sekretariat Negara melakukan verifikasi maka selanjutnya, Kemnesetneg mengirimkan hasil verifikasi tersebut kepada Kejaksaan Agung untuk mendapatkan pertimbangan hukum serta dikirimkan ke DPR untuk dimintakan pertimbangan terhadap komisi yang berkaitan dengan persoalan hukum.

3. Setelah dilakukan pembahasan dan pertimbangan, pemberian amnesti terhadap seorang pemohon amnesti diintrodusir kembali oleh kemensetneg dari

21 M

Nasir

Djamil.https://nasional.sindonews.com/berita/1424986/18/men gakhiri-deritakorban-pasal-karet / diakses tanggal 20 Mei 2021 
Kejaksaan Agung dan DPR untuk selanjutnya diberikan Presiden.

4. Melalui kewenangannya, pemberian amnesti akan dilakukan oleh presiden setelah berkonsultasi kembali dengan Dewan pertimbangan Presiden (WANTIMPRES).

5. Setelah melalui berbagai prosedur tersebut, pemberian amnesti akan dilakukan oleh Presiden melalui Kepres tentang pemberian amnesti.

6. Perlu diatur pula tentang tenggat waktu yang akan diberikan oleh DPR dalam pertimbangannya amnesti kepada presiden

Pemberian amnesti yang sejarahnya merupakan bentuk pengampunan yang diberikan kepada tahanan politik maupun narapidana politik jangan meminta pertimbangan Dewan Perwakilan Rakyat karna yang dibutuhkan adalah pertimbangan Hukum maka dari itu meminta pertimbangan Mahkamah Agung untuk menentukan sesuatu itu merupakan tindak pidana atau bukan. Sementara itu, DPR memberikan pertimbangan dalam hal pemberian Amnesti dan Abolisi karena didasarkan pada pertimbangan politik. Bagir Manan kurang sependapat dengan rumusan tersebut, karena pemberian Amnesti dan Abolisi tidak selalu terkait dengan pidana politik. Kalaupun diperlukan pertimbangan, cukup dari Mahkamah Agung. DPR adalah badan politik, sedangkan yang diperlukan adalah pertimbangan hukum. Pertimbangan politik, kemanusiaan, sosial, dan lain-lain, merupakan isi dari hak prerogatif Presiden. Hal yang diperlukan adalah pertimbangan hukum untuk memberi dasar yuridis pertimbangan Presiden..$^{22}$ Mengikut sertakan DPR dalam amnesti dan abolisi, dapat diperkirakan berdasarkan asumsi karena amnesti dan abolisi sebagai tindakan politik. Hal ini agak ganiil karena amnesti, abolis, rehabilitasi termasuk grasi adalah hak konstitusional Presiden yang lazim disebut hak prerogatif. Dikatakan semestinya penggunaan hak tersebut tidak dicampuri oleh lembaga lain, pertimbangan grasi oleh Mahkamah Agung karena menyangkut putusan pengadilan.

Pengaturan Presiden harus meminta Pertimbangan DPR dalam hal pemberian peniadaan proses hukum (Amnesti) dan pengampunan tuntuttan hukum (Abolisi) perlu untuk di pertimbangkan kembali, hal didasari dengan landasan pemikiran bahwa DPR sebagai lembaga Politik tentu saja paradigma yang dibangun adalah paradigma politik padahal pada konsepnya proses pemberian amnesti dan abolisi adalah masuk dalam ranah politik. Sehingga ketentuan sebagaimana yang diatur dalam pasal 14 ayat 2 UUD NRI tahun 1945 seharusnya dikembalikan pada posisi semula, yakni harus meminta pertimbangan dari Lembaga Peradilan yang dalam hal ini adalah Mahkamah Agung sebagai lembaga negara yang berada di ranah hukum, sehingga

${ }^{22}$ Bagir Manan, Perkembangan..., Op. Cit., hal. 35 dapat memberikan pertimbangan dalam aspek yuridis terhadap pemberian Amnesti dan Abolisi.

Menurut penulis, jika kita memaknai bahwa pemberian grasi merupakan suatu perkara yustisial, seharusnya presiden memerhatikan dengan sungguhsunguh pertimbangan MA. Dan jika grasi dinilai bukan merupakan tindakan eksekutif di ranah yudisial, maka tidak perlu adanya pertimbangan MA. Sebab eksistensi kedudukan MA merupakan pelaku kekuasaan kehakiman (Yudisial). Barangkali lembaga MA kita tempatkan, dimana presiden dalam memberikan pertimbangan dari MA sehingga DPR tidak terlihat. Karena untuk tidak memberikan kemungkinan campur tangan politik mempengaruhi keputusan MA. Menurut Jazim Hamidi dan Mustafa Lutfi berpendapat bahwa jika diamati lebih jauh, yang dapat diketahui dari hubungan keduanya terdapat hubungan yang bersifat politis. Karena pertimbangan yang diberikan oleh DPR merupakan hasil perundingan para elit politik yang ada di dalamnya. Hal ini dapat dilihat dari alasan-alasan politis pimpinan lembaga negara dalam pengangkatan duta dan konsul tersebut. Sama halnya dengan proses pembuatan undang-undang, yang lahir dari para kepentingan para elit politik dan dibungkus dengan atas nama kepentingan rakyat. Padahal, tidak sedikit dari produk legislatif tersebut sama sekali tidak berpihak pada rakyat. ${ }^{23}$

Salah satu hal yang harus diperhatikan dalam prosedur pemberian amnesti adalah adanya keterbukaan terhadap pemberian amnesti yang dapat diketahui dan diakses oleh publik. Dalam hal demikian, pemberian amnesti harus secara terbuka diumumkan oleh Presiden dengan menjelaskan latar belakang pilihan terhadap diambilnya kebijakan memberikan amnesti tersebut. hal ini dimaksudkan agar tidak akan lahir persepsi terhadap pemberian amnesti yang dilakukan secara sepihak tanpa mempertimbangkan berbagai aspek dan berbagai masukan dari pihak-pihak lain yang mempunyai hubungan dengan Presiden. menjadi persoalan amnesti meniadakan hukuman akibat perbuatan seseorang, jika tak diperlakukan benar dan hati-hati, maka dapat mengesankan ada penambahan di tingkat peradilan Indonesia. Amnesti dapat menjadi tingkat peradilan kelima setelah PK, Kasasi, Banding Pengadilan Tinggi dan Putusan Pengadilan Negeri. Sebab, dia menambahkan, tidak mustahil akan banyak narapidana mengajukan amnesti yang merasa sampai dengan tingkat Peninjauan Kembali (PK) merasa diperlakukan tidak adil seperti Baiq Nuril. Jika ini yang terjadi sulit dibayangkan dunia peradilan Indonesia sebagai kekuasaan yudikatif dengan mudah diintervensi eksekutif.

23 Jazim Hamidi dan Mustafa Lutfi, 2010, Hukum Lembaga Kepresidenan Indonesia, Alumni, Bandung, Hlm 53. 


\section{SIMPULAN}

Hak prerogatif Presiden dalam melakukan pengangkatan maupun pemberhentian menteri tampaknya juga memperhatikan keterwakilan perempuan dalam kabinet. Langkah pimpinan tertinggi negara ini telah mencerminkan adanya upaya untuk tidak menciptakan prinsip diskriminatif pada seluruh warga negara. Kedepannya, keterwakilan menteri perempuan pada kabinet pemerintahasama sekali. Oleh sebab itu, seluruh elemen negara harus mampu memberikan masukan kepada Presiden selaku pihak yang memegang hak mutlak atas keterwakilan perempuan pada kabinet pemerintahan, agar representasi menteri negara mendapatkan keseimbangan komposisi antara menteri laki-laki maupun menteri perempuan.

\section{DAFTAR PUSTAKA}

\section{Buku}

Bagir Manan, Pertumbuhan dan Perkembangan Konstitusi Suatu Negara, Cetakan 1, Bandung: Penerbit CV. Mandar Maju, 1995.

C.S.T Cansil, Sistem Pemerintahan Indonesia, Aksara Baru, Jakarta, 1985.

Ismail Suny, Pembagian Kekuasaan Negara, Jakarta: Aksara Baru, 1978.

James N. Rosenau (ed.). International Politics and Foreign Policy.London: the Free Press, tanpa tahun.

Jazim Hamidi dan Mustafa Lutfi, 2010, Hukum Lembaga Kepresidenan Indonesia, Alumni, Bandung, tanpa tahun.

Jimly Asshidiqie. Pokok-Pokok Hukum Tata Negara Indonesia. Pasca Reformasi, (Jakarta: PT Bhuana Ilmu Populer, 2007.

Norman J. Padelford and George A. Lincoln, International Politics, The Macmillan Company, New York, 1960.

\section{Jurnal}

I.G Iakovenko. Dynamic Interest. Dimuat dalam Russian Politic and Law Vol. 38, no. 6, NovemberDecember 2000.

J. Martin Rochester. The national interest and contemporary world politics. The review of politics Vol. 40 No. 1, 1978.

Kontras. Mempertimbangkan Amnesti Bagi Tahanan Politik Papua. 2012.

Siti Rakhma Mary Herwati,Pemberian Amnesti, Abolisi, dan Rehabilitasi untuk Para Pejuang Agraria Demi Keadilan, Bogor: Policy Paper Sajogyo Institute No. 1, 2015.

S.S Mirotokhin. The Potential of National interest. Dimuat dalam Russian Politic and Law Vol. 38, no. 6, November-December 2000.

\section{Sumber Internet/Website}

BBC News, Kasus Baiq Nuril: Perempuan yang dipidanakan karena merekam percakapan mesum akan 'tagih amnesti' ke Jokowi, artikel, dimuat dalam https://www.bbc.com/indonesia/indonesia48878086

M Nasir Djamil, diakses pada laman https://nasional.sindonews.com/berita/1424986/18 Imengakhiri-derita-korban-pasal-karet

Telaah kasus Din Minimi Dalam Sudut Pandang Hukum, Politik dan Korban http://www.jsithopi.org/2016/02/telaah-kasus-dinminimi-dalam-sudut-pandang-hukum-politik-dan$\underline{\text { korban }}$

\section{Peraturan Perundang-Undangan}

Human Rights Committee General Comment No. 34, UN Doc. CCPR/C/GC/34, September 2011

Undang-Undang Darurat Nomor 11 tahun 1954 Tentang Amnesti dan Abolisi 